\title{
Parotocinclus seridoensis, a new hypoptopomatine catfish (Siluriformes: Loricariidae) from the upper rio Piranhas-Açu basin, northeastern Brazil
}

\author{
Telton Pedro A. Ramos ${ }^{1}$, Luciano F. Barros-Neto', Heraldo A. Britski \\ and Sergio M. Q. Lima ${ }^{1}$
}

A new species of Parotocinclus is described from the upper rio Piranhas-Açu basin, northeastern Brazil. The new species differs from all its congeners, except P. bidentatus, P. muriaensis (both from rio Paraíba do Sul basin, southeastern Brazil), and $P$. spilurus (rio Jaguaribe basin, northeastern Brazil) by presenting the adipose fin rudimentary or absent. The new species differs from P. bidentatus, P. muriaensis, and P. spilurus mainly by presenting the abdomen region extensively naked, with few reduced rounded dermal platelets between the pectoral girdle and the anus. Parotocinclus seridoensis is probably an endemic species of the semi-arid Caatinga, region where the genus presents high species richness.

Uma espécie nova de Parotocinclus é descrita da bacia do alto rio Piranhas-Açu, nordeste do Brasil. A espécie nova difere de todas as congêneres, exceto P. bidentatus, P. muriaensis (ambas da bacia do rio Paraíba do Sul, sudeste do Brasil) e P. spilurus (bacia do rio Jaguaribe, nordeste do Brasil), por apresentar nadadeira adiposa rudimentar ou ausente. A espécie nova difere de P. bidentatus, $P$. muriaensis e $P$. spilurus principalmente por apresentar no abdômen extensas áreas nuas, com poucas placas dérmicas reduzidas e arredondadas entre a cintura peitoral e o ânus. Parotocinclus seridoensis é provavelmente uma espécie endêmica da Caatinga semi-árida, região onde o gênero apresenta elevada riqueza de espécies.

Key words: Mid-Northeastern Caatinga region, Rio São Francisco transposition, Semi-arid Caatinga, Taxonomy, Temporary rivers.

\section{Introduction}

The genus Parotocinclus Eigenmann \& Eigenmann comprises 26 valid nominal species of small hypoptopomatine catfishes, known in Brazil as "cascudinhos", widely distributed in the Neotropical Cis-Andean region, extending from Venezuela to southern Brazil (Sarmento-Soares et al., 2009; Lehmann \& Reis, 2012; Lehmann et al., 2013). The Hypoptopomatinae is a monophyletic subfamily within the Loricariidae that currently includes 20 genera (Carvalho et al., 2008; Reis et al., 2012), in spite of the controversial monophyletic condition of the genus Parotocinclus (Schaefer, 1998; Ribeiro et al., 2002; Gauger \& Buckup, 2005; Sarmento-Soares et al., 2009).

Parotocinclus was originally described as a monotypic subgenus of Hisonotus by Eigenmann \& Eigenmann (1889), and the same authors (1890) raised its condition to the genus level, mainly due to the presence of an adipose fin. Schaefer (1991) recognized the genus as monophyletic, using three putative characters: 1) robust short crest on hyomandibula separating the adductor mandibulae of the cheek from the dilator and levator operculi muscles; 2) first dorsal-fin spinelet large, and 3) lateral line interrupted, terminating two to four plates preceding the last lateral plate. However, according to morphological parsimony phylogenetic analysis Parotocinclus was recognized as a polyphyletic assemblage (Gauger \& Buckup, 2005). Lehmann (2006) also recognized the genus as a highly paraphyletic group of species, thus needing a formal revision and the erection of new genera to accommodate the species previously assigned to Parotocinclus, but not closely related to the type species $P$. maculicauda (Steindachner).

${ }^{1}$ Laboratório de Ictiologia Sistemática e Evolutiva, Departamento de Botânica, Ecologia e Zoologia, Universidade Federal do Rio Grande do Norte, 59978-970 Lagoa Nova, Natal, RN, Brazil. telton@gmail.com (TPAR), cdp_luciano@hotmail.com (LFBN), smaialima@gmail. com (SMQL)

${ }^{2}$ Museu de Zoologia da Universidade de São Paulo, Caixa Postal 42494, Ipiranga, 04299-970 São Paulo, SP, Brazil. heraldo@usp.br 
The goal of the present paper is to describe a new species of Parotocinclus from the rio Piranhas-Açu basin, northeastern Brazil, with adipose fin rudimentary or absent. In northeastern region of Brazil, Parotocinclus presents a high species richness, represented by eleven species described until the present study: P. arandai SarmentoSoares, Lehmann \& Martins-Pinheiro, P. bahiensis (Miranda Ribeiro), P. cearensis Garavello, P. cesarpintoi Miranda Ribeiro, P. cristatus Garavello, P. haroldoi Garavello, P. jimi Garavello, $P$. jumbo Britski \& Garavello, P. minutus Garavello, P. spilosoma (Fowler) and P. spilurus (Fowler) (Sarmento-Soares et al., 2009; Lehmann \& Reis, 2012). Some of these species are found in temporary rivers of the semi-arid Caatinga region (Garavello, 1977).

\section{Material and Methods}

Specimens were fixed in formalin for approximately two weeks, and then transferred to $70 \%$ ethanol. Measurements and counts followed Carvalho \& Reis (2009). Counting of longitudinal plate series followed Britski \& Garavello (2009), while osteological nomenclature followed Schaefer (1997). Measurements were taken with a digital caliper, and recorded to tenths of a millimeter. Descriptions of color pattern are based on photographs of live individuals kept in aquaria after collection. Measurements are presented as percents of standard length (SL) or head length (HL). Osteological examinations were performed on cleared and double-stained for bone and cartilage (c\&s) specimens according to the procedure of Taylor $\&$ Van Dyke (1985). Vertebral counts included all vertebrae of the Weberian apparatus and the compound caudal centrum (PU1+U1) counted as a single element.

Three paratypes were fixed and stored in ethanol 99.3\%, and deposited in Laboratório de Ictiologia Sistemática e Evolutiva, Universidade Federal do Rio Grande do Norte (UFRN 5 and UFRN 240), for future molecular studies. Abbreviation for institutions are: MCP, Museu de Ciências e Tecnologia, Pontifícia Universidade Católica do Rio Grande do Sul, Porto Alegre; MNRJ, Museu Nacional, Rio de Janeiro; MZUSP, Museu de Zoologia da Universidade de São Paulo, São Paulo; UFPB, Universidade Federal da Paraíba, João Pessoa, and UFRN, Universidade Federal do Rio Grande do Norte, Natal.

\section{Parotocinclus seridoensis, new species}

Fig. 1

Holotype. MZUSP 113422, 37.7 mm SL (Female); Brazil, Rio Grande do Norte State, Caicó Municipality, rio Seridó, rio PiranhasAçu basin, 6²7'28.4”S 3705'10.7'W, 11 Jun 2012, S. Lima, W. Berbel, L. Neto, C. Neves, C. Alencar, D. Ferreira \& F. Landim. Paratypes. All from Brazil, rio Piranhas-Açu basin. Rio Grande do
Table 1. Morphometric data of holotype (MZUSP 113422) and 24 paratypes of Parotocinclus seridoensis. Abbreviations: $\mathrm{SD}$, standard deviation.

\begin{tabular}{lcccc}
\hline & Holotype & \multicolumn{3}{c}{ Paratypes } \\
\cline { 3 - 5 } & & Range & Mean & SD \\
\hline Standard length (mm) & 37.6 & $25.1-42.6$ & 32.6 & - \\
Percentages of standard length & & & & \\
Body depth & 18.5 & $14.7-20.2$ & 17.1 & 1.3 \\
Head length & 22.6 & $33.0-38.0$ & 36.1 & 1.8 \\
Cleithral width & 28.1 & $26.2-28.5$ & 27.4 & 0.6 \\
Trunk length & 18.2 & $14.5-18.2$ & 16.4 & 1.1 \\
Abdominal length & 21.6 & $19.3-23.0$ & 21.1 & 0.9 \\
Pectoral-fin length & 23.6 & $22.1-26.4$ & 24.4 & 1.2 \\
Caudal-peduncle depth & 11.4 & $9.7-11.7$ & 10.7 & 0.5 \\
Caudal-peduncle length & 32.6 & $29.6-32.9$ & 31.2 & 1.9 \\
Predorsal length & 47.9 & $43.9-48.5$ & 46.6 & 1.1 \\
Percentages of head length & & & & \\
Head depth & 44.9 & $40.5-49.0$ & 44.1 & 2.2 \\
Snout length & 56.0 & $47.6-56.1$ & 52.1 & 1.9 \\
Horizontal eye diameter & 13.7 & $13-7-17.9$ & 15.2 & 1.1 \\
Interorbital width & 35.1 & $32.2-38.7$ & 36.1 & 1.4 \\
\hline
\end{tabular}

Norte. MZUSP 113423, 3, 33.6-41.8 mm SL; MNRJ 40715, 1, 31.6 mm SL; UFRN 240, 1, 30.6 mm SL; same data as holotype. MNRJ 40716, 5, 26.1-35.2 mm SL; MZUSP 113424, 6, 26.9-36.9 mm SL; UFPB 9218, 5, 28.1-39.7; UFRN 005, 4, 29.8-37.0 mm SL (2 c\&s); same locality as holotype, 04 May 2011, P. Medeiros \& J. Medeiros. UFRN 303, 1, $34.2 \mathrm{~mm}$ SL, Jardim de Piranhas Municipality, rio Piranhas, 6²2'40.3”S 37²1'19.3”W, 13 Jun 2012, S. Lima, W. Berbel, L. Neto, C. Neves, C. Alencar, D. Ferreira \& F. Landim. Paraíba. UFRN 1588, 1, 32.18 mm SL, Pombal Municipality, rio Piranhas, 643'12.1'’S 3747'11.6”'W, 13 Apr 2013, M. Silva; MCP 31463, 19, 24.0-34.5 mm SL (2c\&s), rio Piranhas in BR-230 between Pombal and Souza, $5 \mathrm{Km}$ of Pombal, 643'31.9”S 3747'49.9'W, 20 Nov 2002, C. Lucena, E. Pereira \& J. Pezzi. UFRN 1590, 1 c\&s, 35.4 mm SL, Ibiara Municipality, rio Piancó, 7²8'33.7'S 38²1'10.3”'W, 24 Apr 2013, T. Ramos, L. Neto, R. Paiva \& M. Germano.

Diagnosis. The new species differs from all its congeners, except Parotocinclus bidentatus Gauger \& Buckup, P. muriaensis Gauger $\&$ Buckup and P. spilurus (Fowler) by presenting adipose fin rudimentary or absent. Parotocinclus seridoensis differs from $P$. bidentatus, $P$. muriaensis and P. spilurus by presenting abdomen almost naked, with a single row of elongate reduced plates on each side and a group of small rounded plates irregularly distributed on preanal region ( $v s$. abdomen completely covered of dermal plates between the pectoral girdle and the anus), and also by presenting bright spots, usually about as large as the eye diameter or larger on sides of the body predominantly disposed in two rows (dorsally and ventrally) (vs. body without spots in P. bidentatus and $P$. muriaensis; and with numerous small bright spots about as 


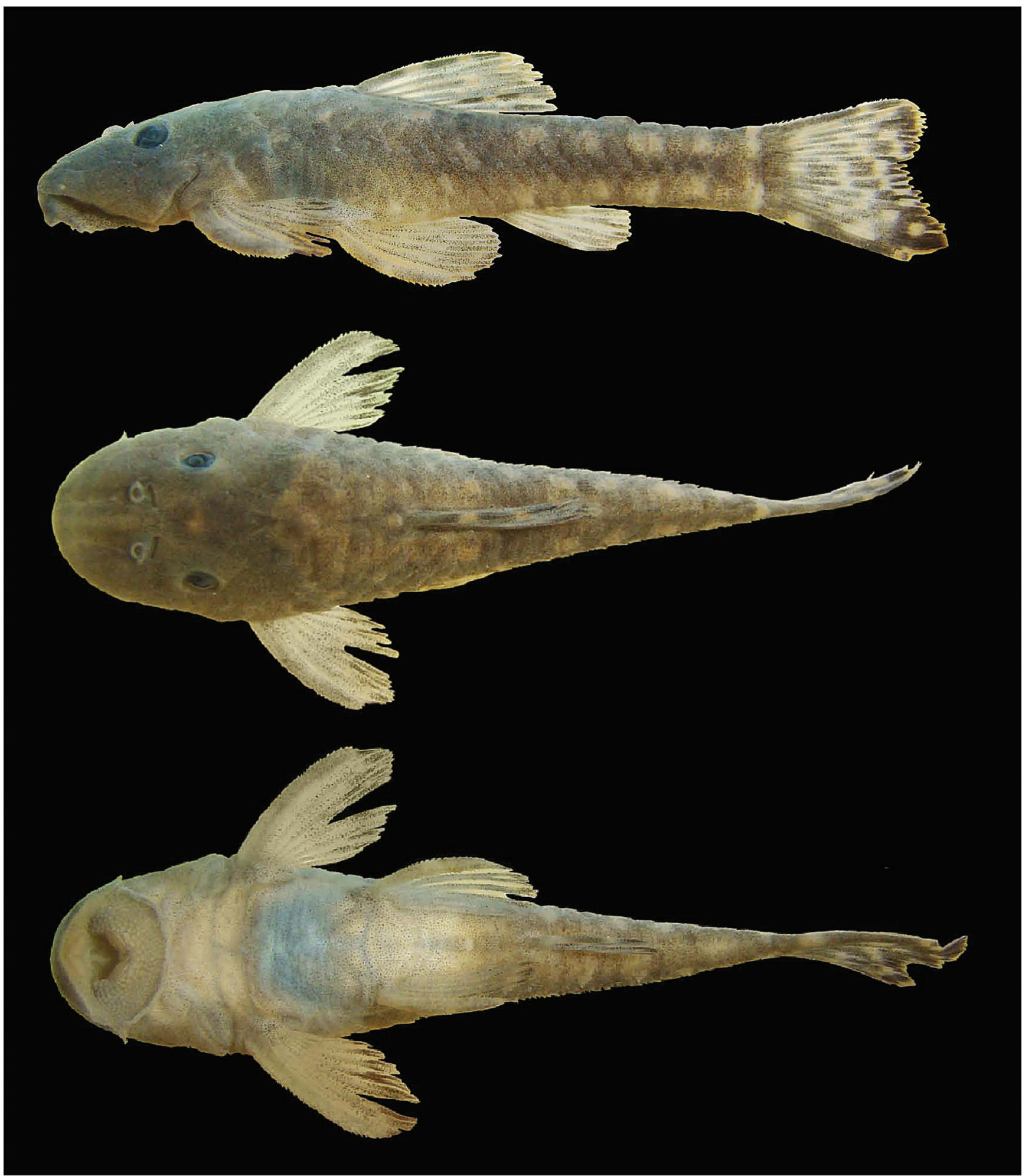

Fig. 1. Parotocinclus seridoensis, holotype, MZUSP 113422, 37.7 mm SL, female, Brazil, Rio Grande do Norte State, Caicó Municipality, rio Seridó, rio Piranhas-Açu basin. Lateral, dorsal, and ventral views.

large as pupil diameter scattered on body and head in P. spilurus). Parotocinclus seridoensis also differs from $P$. bidentatus and $P$. muriaensis, but not to P. spilurus by the presence of of pectoral girdle medially covered by skin and laterally exposed, supporting odontodes only laterally (vs. completely exposed). It also differs from $P$. spilurus by the presence of an area deprived of odontodes at the anterior border of the snout shaped as an inverted $\mathrm{V}$ or U (vS. anterior border of the snout covered by regular rows of odontodes). 
In addition to the adipose fin rudimentary or vestigial Parotocinclus seridoensis is further distinguished from congeners of northeastern Brazil, except $P$. arandai, $P$. cearensis, P. cesarpintoi, P. jumbo, P. minutus, and P. spilosoma, by having abdomen nearly naked, with only one or two row of plates on each side and median row of platelets irregularly distributed ( $v s$. abdomen entirely covered by larges plates between the pectoral girdle and preanal region in P. cristatus, P. jimi, and P. haroldoi, and abdomen completely naked with only preanal platelets in $P$. bahiensis). Parotocinclus seridoensis also shares with $P$. bahiensis, $P$. cearensis, and $P$. jumbo the pectoral girdle covered by skin medially and laterally exposed, and supporting odontodes only laterally ( $v s$. scapular bridge completely exposed in $P$. arandai, $P$. cesarpintoi, $P$. cristatus, P. jimi, P. haroldoi, P. minutus, and P. spilosoma).

Description. Morphometric and meristic data of holotype and paratypes are presented in Table 1 and 2. Body up to $42.6 \mathrm{~mm}$ SL. Body moderately short and somewhat depressed. Greatest body width at cleithrum, progressively tapering to end of caudal peduncle. Dorsal profile slightly convex from snout to parietosupraoccipital tip; straight between parieto-supraoccipital and dorsal fin origin; descendent at dorsal-fin base; slightly concave from dorsal-fin end to rudimentary adipose fin (or azygous plate indicating its position); straight or slightly concave from this point to base of uppermost caudal-fin rays. Ventral body profile of head straight or slightly concave; ventral profile of trunk somewhat straight from pectoral girdle to posterior base of pelvic fin; somewhat concave at anus region, straight at anal-fin base and straight from anal-fin end to lowermost caudal-fin rays. Head depressed and round in dorsal view. Eyes moderately small, positioned midway between snout tip and pterotic-supracleithrum posterior margin; distance between orbit margin and ventral surface of head greater than orbital diameter. Dorsal iris diverticulum present. Interorbital space straight or
Table 2. Meristic data of holotype (MZUSP 113422) and 24 paratypes of Parotocinclus seridoensis.

\begin{tabular}{lccc}
\hline & Holotype & \multicolumn{2}{c}{ Paratypes } \\
\cline { 3 - 4 } & & Range & Mode \\
\hline Premaxillary teeth right & 21 & $14-21$ & 17 \\
Premaxillary teeth left & 21 & $14-21$ & 16 \\
Dentary teeth right & 21 & $14-22$ & 16 \\
Dentary teeth left & 21 & $11-22$ & 19 \\
Plates in median lateral series & 23 & $23-24$ & 23 \\
Plates at dorsal-fin base & 5 & $4-5$ & 5 \\
Plates at anal-fin base & 2 & 2 & 2 \\
Plates between anal and caudal fins & 10 & 10 & 10 \\
\hline
\end{tabular}

slightly convex. Pectoral girdle exposed only laterally; median region covered by skin (Fig. 3); coracoids laterally covered by odontodes; arrector fossae ellipsoid, small, extending laterally, almost meeting in at midline (Fig. 4). Snout rounded in dorsal view. Greatest body depth at dorsal-fin origin. Individuals with two depressions on snout; inferior rostral margin of snout with posteriorly directed odontodes similar in size to those on dorsal portion of snout, sometimes with an area variable in extension deprived of odontodes at the anteroventral border of snout shaped as an inverted $\mathrm{V}$ or $\mathrm{U}$. Odontodes on upper part of head, roughly arranged in rows. Mouth small. Oral disk approximately round, papillose; maxillary barbels slightly shorter than orbital diameter. All teeth slender and bifid. Accessory patch of uniscupid teeth absent. Head depressed and round in dorsal view. Eye moderately small and dorsolaterally positioned; distance between ventral margin of orbit and ventral surface of head greater than orbital diameter. Trunk depressed on insertion of dorsal and anal fin. Caudal peduncle rounded in cross section.

Dorsal fin i,7; its origin slightly posterior to pelvic-fin origin; dorsal fin when adpressed extending to vertical through

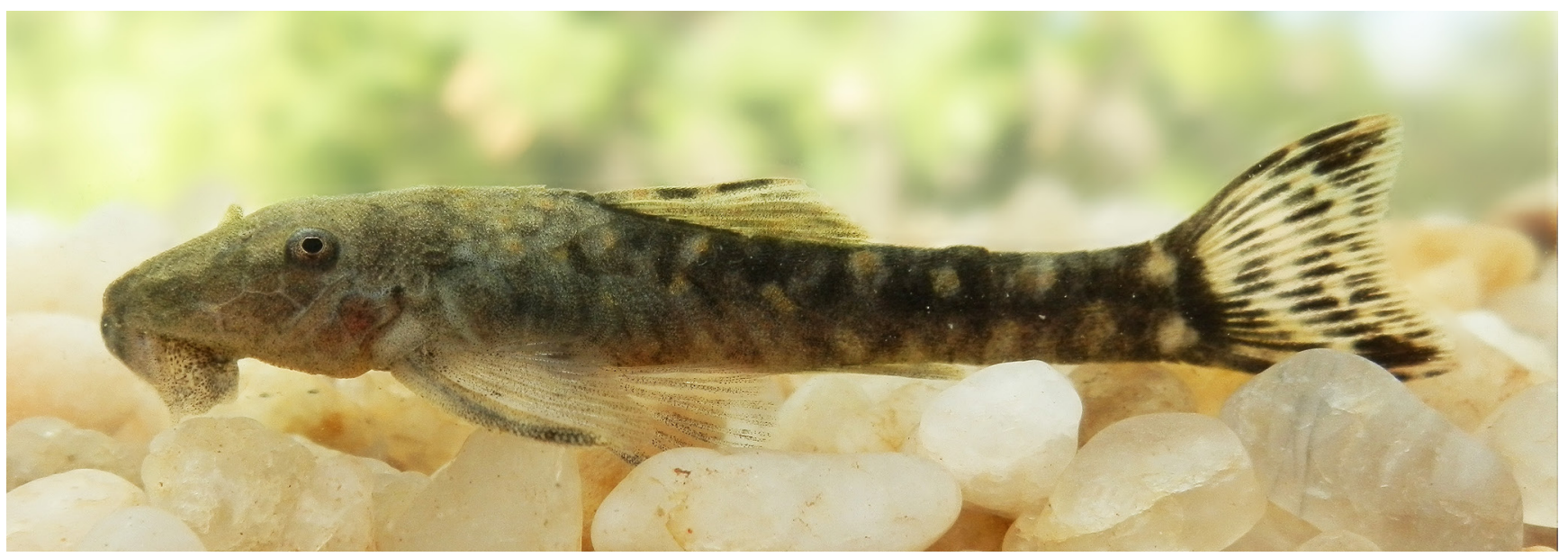

Fig. 2. Parotocinclus seridoensis, live paratype specimen, UFRN 240, $30.6 \mathrm{~mm}$ SL, from rio Seridó (type locality), Caicó, Rio Grande do Norte, just after collection. 


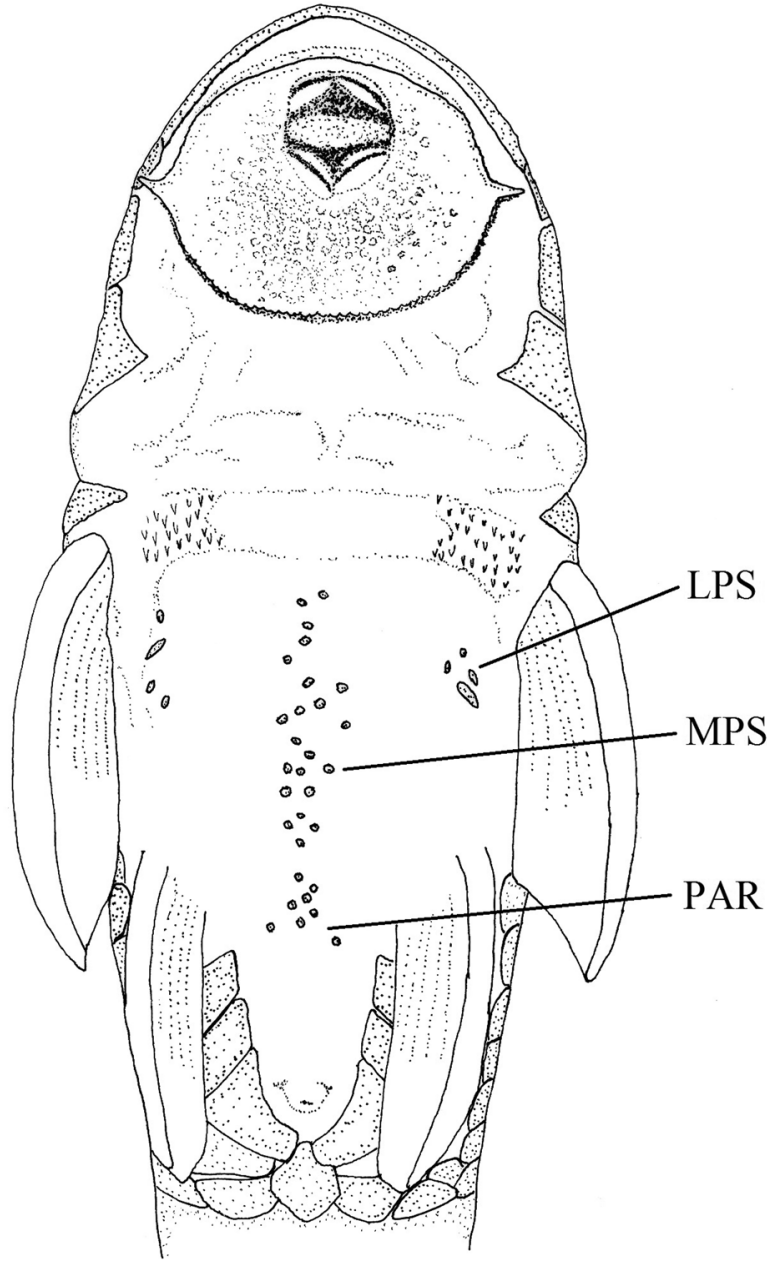

Fig. 3. Ventral view of abdominal region showing the lateral plates and preanal platelets in Parotocinclus seridoensis, UFRN 005, $37.0 \mathrm{~mm}$ SL, female. Abbreviations: LPS, lateral plate series; MPS, median plate series; PAR, preanal region.

beyond anal-fin base. Pectoral fin i,6; pectoral spine reaching one quarter to one third of length of unbranched pelvic-fin ray. Pelvic-fin rays i,5; unbranched ray curved, covered with small odontodes; pelvic fin reaching beyond anus, ending just anterior to anal-fin origin. Anal-fin rays i,5; origin of anal fin covering three plates. Caudal fin slightly notched, emarginate, with lower lobe slightly pointed and longer upper lobe; principal caudal-fin rays i,14,i. Lateral-line canal in median series complete, pore tube visible from pterotic-supracleithrum to caudal peduncle. Abdomen nearly naked; with only one or two row of small plates elongate and rounded on each side arranged near the pectoral girdle, and a group of small rounded plates irregularly distributed on preanal region (Fig. 3); some young individuals with two or three platelets in the middle of abdomen. Dorsal-fin spine flexible, followed by seven branched rays. Dorsal-fin locking mechanism nonfunctional. Nuchal plate exposed, not covered by skin. Dorsal-fin spinelet present, V-shaped, wider than base of dorsal spine. Adipose fin rudimentary or vestigial. Total vertebrae 24 ( $2 \mathrm{c} \& \mathrm{~s})$.

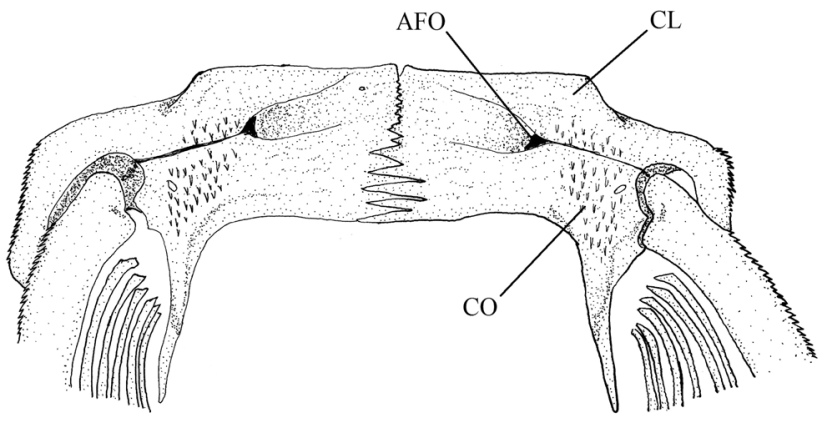

$\underline{1 \mathrm{~mm}}$

Fig. 4. Ventral view of pectoral girdle of Parotocinclus seridoensis, UFRN 005, $30.7 \mathrm{~mm}$ SL, female. Abbreviations: AP, abdominal plates; AFO, arrector fossa opening; CL, cleithrum; $\mathrm{CO}$, coracoid.

Coloration. Ground color in ethanol dark gray to dark brown. Dorsal and lateral portions of head uniform in color with a bright spot on pineal region; ventral area of head yellowish. Trunk with clear spots, usually uniform in size, diameter, form (usually rounded) and distribution, forming sometimes two alternate longitudinal series, dorsally and ventrally, extending from gill opening to caudal peduncle, ending in two conspicuous whitish yellow blotches vertically arranged. Abdomen yellowish white, anterior region (pectoral girdle to anus) with little dark chromatophores, posterior region with conspicuous dark chromatophores. Dorsal and caudal-fin rays with dark chromatophores, forming irregular set of stripes that alternates between dark gray and brownish yellow: three on dorsal fin and four on caudal fin; tip of caudal-fin lobes intensively pigmented with dark chromatophores. Pectoral, pelvic- and anal-fin rays with few and sparse chromatophores forming a set of inconspicuous stripes. Live coloration (Fig. 2) with same pattern described above, only becoming clearer in fixed specimens.

Sexual dimorphism. Males possess urogenital papilla positioned just behind the anal opening and a low fleshy flap along the dorsal margin of the first pelvic-fin ray, that is absent in females.

Distribution. Parotocinclus seridoensis is only known from four localities in the upper rio Piranhas-Açu basin, which is formed by two main tributaries, the rio Piranhas itself in the west, and the rio Serido in the east, in the boundaries of Rio Grande do Norte and Paraíba States. Individuals of the new species were mainly found in rio Seridó, in Caicó Municipality, and in rio Piranhas main channel at Pombal Municipality, while a single specimen was caught in rio Piranhas, Jardim de Piranhas Municipality, upstream the confluence with the rio Seridó, and another in the rio Piancó, Ibiara Municipality, the southernmost record of the species, suggesting a restricted geographic distribution (Fig. 5). 
Etymology. The species epithet seridoensis refers the semiarid Caatinga region, popularly known as "Sertão do Seridó", which encompasses the upper rio Piranhas-Açu basin region in Rio Grande do Norte and Paraíba States, one of the most arid regions in northeastern Brazil, with mean annual rainfall of about $500 \mathrm{~mm}$ (Silva et al., 2006). The etymology of the word "Seridó" is probably derived from the native Indian language expression "ceri-toh". In Tapuia language it means "little foliage and little shade", referring to the characteristic Caatinga vegetation, mainly composed by xeric shrub lands and thorn forest, that consists in small, thorny trees that shed their leaves in the dry periods.

Ecological notes. Specimens were caught in rio Seridó, type locality of the species (Fig. 6), and in the rio Piranhas, both tributaries of the upper rio Piranhas-Açu basin. The "Sertão do Seridó" region is characterized by temporary rivers, due to small precipitation concentrated in few months of the year and high temperatures and evaporation (Rosa et al., 2003). Parotocinclus seridoensis was usually found under large rocks in streams of moderate current flow and clear water (Fig. 6). In these, Parotocinclus jumbo, was found in sympatry, however, inhabiting shallow and narrow streams with laminar flow, sand and gravel substrate, in the rio Seridó, while in the rio Piranhas this microhabitat was found only at the right margin, where $P$. jumbo was observed forming small shoals, behavior already registered by Britski \& Garavello (2002).

Other species collected together with the P. seridoensis in rio Seridó were: Astyanax aff. bimaculatus, Hemigrammus marginatus Ellis, Moenkhausia sp., Characidium bimaculatum Fowler, Hoplias malabaricus (Bloch), Prochilodus brevis Steindachner.

Hypostomus pusarum (Starks), Pseudancistrus papariae Fowler, Poecilia vivipara Bloch \& Schneider, Cichlasoma orientale Kullander, Crenicichla menezesi Ploeg, and Oreochromis niloticus (Linnaeus), the last one a widespread introduced species in northeastern Brazil (Medeiros et al., 2010). In addition to these species, in rio Piranhas were also collected: Serrasalmus rhombeus (Linnaeus), Triportheus signatus (Garman) and Trachelyopterus galeatus (Linnaeus).

During ichthyological surveys in the upper rio PiranhasAçu, some of the above mentioned species were only found in fast-flowing rivers, just as the rio Piranhas at Jardim de Piranhas, and the rio Seridó at Caicó, both temporary rivers made perennial by water release from Açude de Coremas and Passagem das Traíras dams, respectively. With the river disconnection by weirs and dams constructions, it is possible

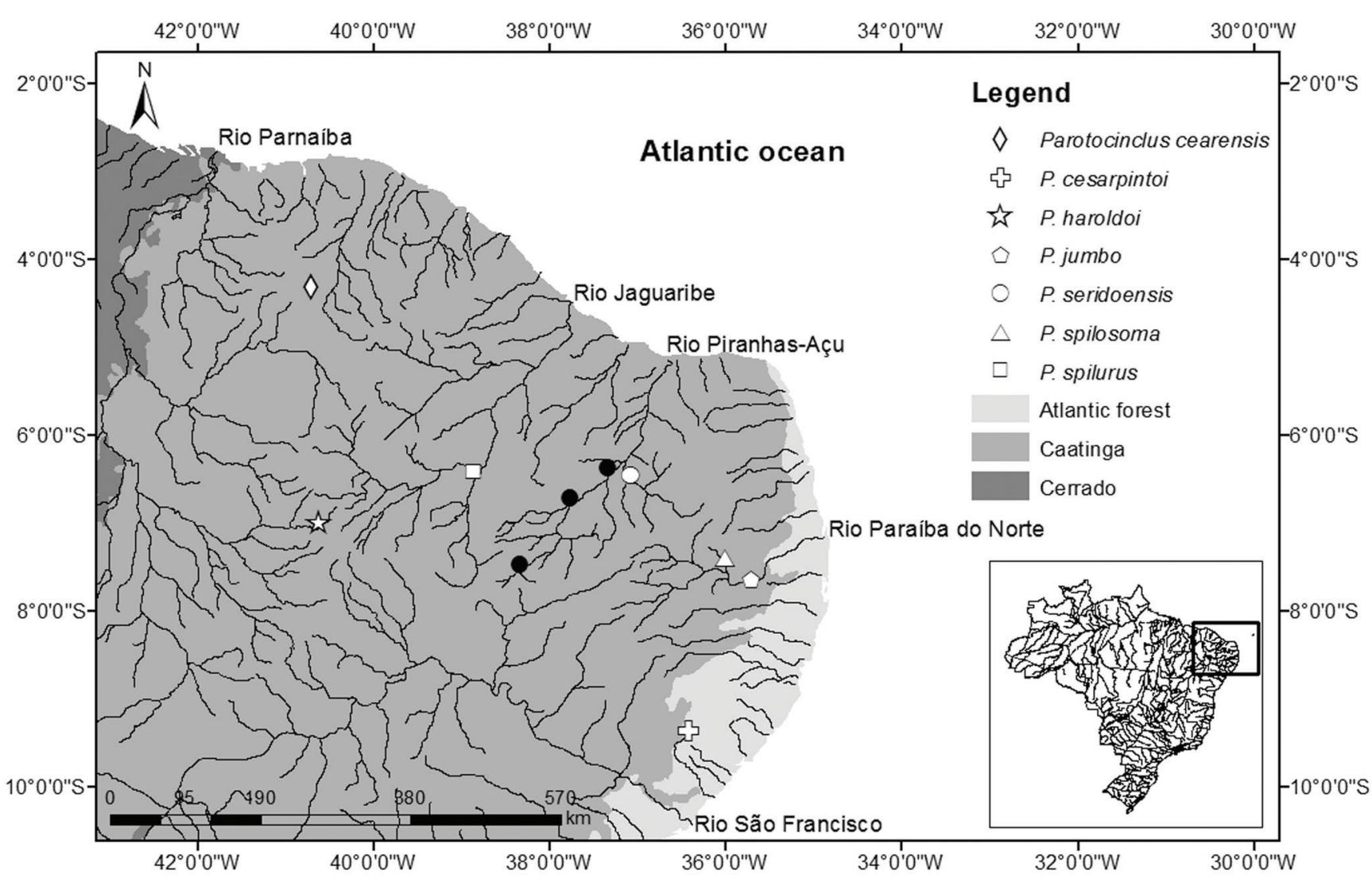

Fig. 5. Geographic distribution of Parotocinclus species in Mid-Northeastern Caatinga region and rio Parnaíba basin, northeastern Brazil. Open symbols represents type localities. 


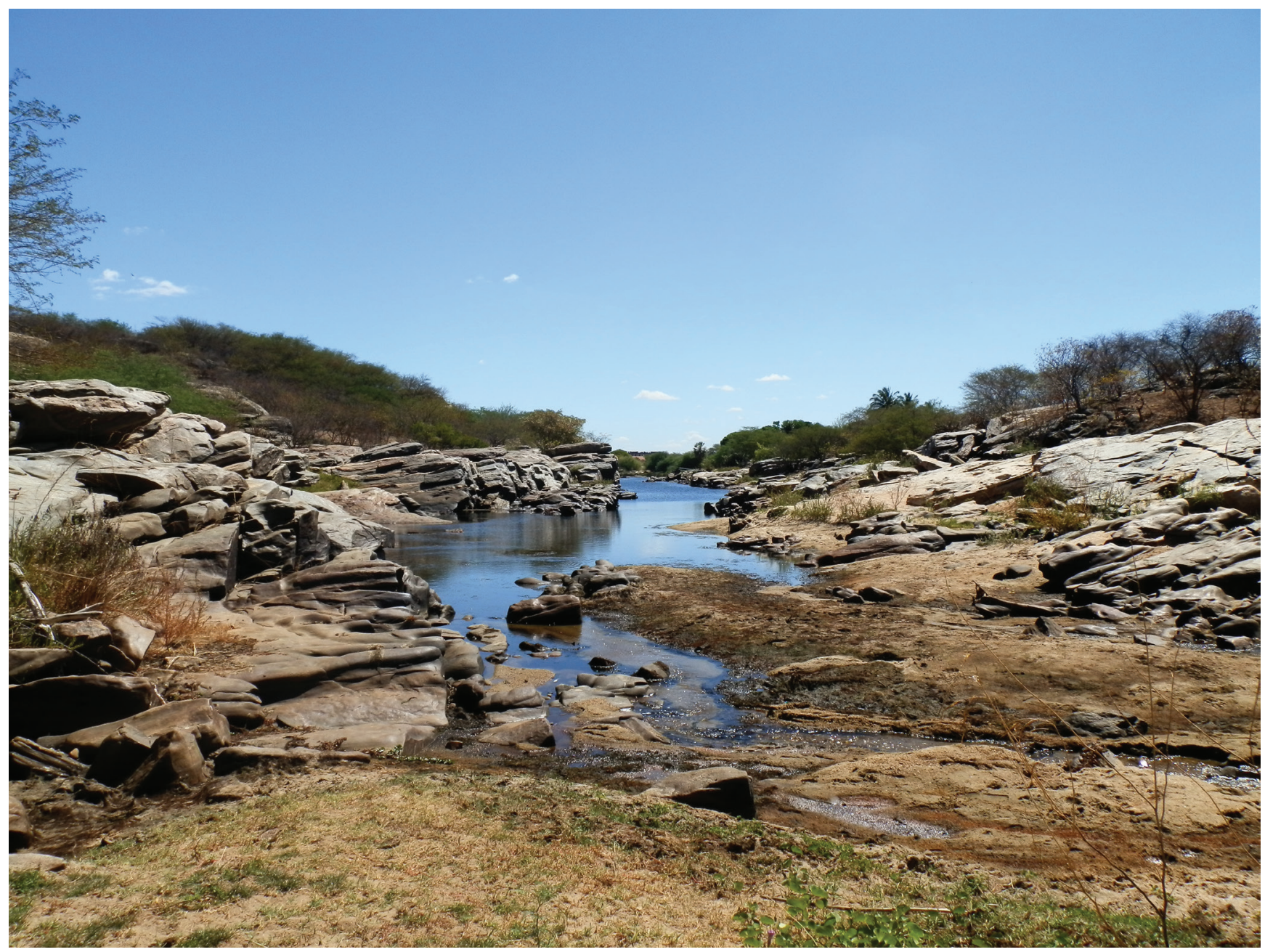

Fig. 6. Type locality of Parotocinclus seridoensis, Brazil, Rio Grande do Norte State, Caicó, rio Seridó, rio Piranhas-Açu basin.

that these artificially perennial river stretches could represent important role in maintaining populations of rheophilic species that couldn't reach the headwaters upstream during dry periods.

Gastrointestinal contents of two specimens of $P$. seridoensis was mainly composed by benthic invertebrates (Chironomidae and Coleoptera larvae) in one specimen (UFRN 005, $30.7 \mathrm{~mm} \mathrm{SL}$ ), while the other presented the tract filled with silt (UFRN 1590, $35.4 \mathrm{~mm} \mathrm{SL}$ ).

Conservation remarks. The rio Piranhas-Açu basin is one of the largest temporary rivers of the semi-arid northeastern Brazilian area, constantly affected by drought, that will receive water from the controversial project of the artificial watershed transposition of the perennial rio São Francisco (Lima, 2005). Although it could ensure water supply to rural and urban local people, diverting water from the rio São Francisco basin can cause many harmful environmental impacts to the aquatic biota of the river basins of the Mid-Northeastern Caatinga region, which encompasses the basins east to rio Parnaíba and north to rio São Francisco (Rosa, 2004; Abell et al., 2008). Among these potential impacts to the aquatic organisms are: the intake of several species in the receiving basins, changes in the structure and composition of aquatic communities, species hybridization, loss of local adaptations, and local extirpation or extinction of endemic species (Langeani et al., 2009), just as P. seridoensis.

\section{Discussion}

Pending an ongoing phylogenetic study involving the relationships within the Loricariidae, including the Hypoptopomatinae, and a redefinition of Parotocinclus and allied genera, the new species is herein assigned to Parotocinclus. According to Lehmann (2006), P. seridoensis (identified as Parotocinclus sp. n. 10) is closely related to $P$. cesarpintoi, $P$. haroldoi, and P. spilurus, all species from the northeastern Brazil.

Although the presence of adipose fin is traditionally used as a diagnostic feature of Parotocinclus, a rudimentary or absent adipose fin was also observed in P. bidentatus, $P$. muriaensis, and P. spilurus (Fowler, 1941; Gauger \& Buckup, 2005). In these species the adipose fin is represented by two small unpaired plates (Gauger \& Buckup, 2005) forming a vestigial 


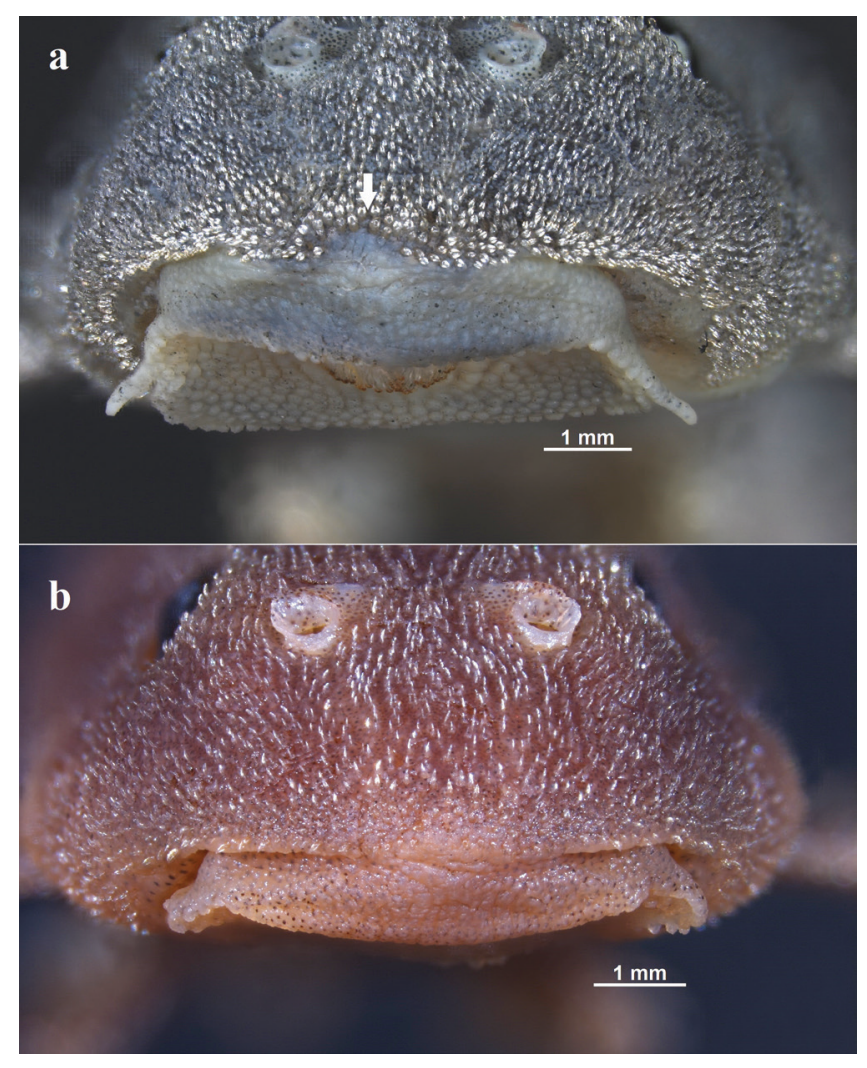

Fig. 7. Anterior view of rostrum of: a. Parotocinclus seridoensis, MZUSP 113424, $33.4 \mathrm{~mm} \mathrm{SL}$, showing an area deprived of odontodes (arrow) at the anterior border of the snout; $b$. Parotocinclus spilurus, UFPB 336, $29.6 \mathrm{~mm}$ SL, with anterior border of the snout covered by odontodes.

ridge, although it is usually slightly more developed, and easily to be observed in lateral view, in $P$. spilurus than in $P$. seridoensis. Parotocinclus bidentatus and P. muriaensis were described from the rio Paraíba do Sul basin, and differ from most species of Parotocinclus, including P. seridoensis and $P$. spilurus, by the presence of accessory unicuspid teeth located internally to the series of bicuspid teeth on premaxillary and dentary bones (Gauger \& Buckup, 2005).

Parotocinclus spilurus and P. seridoensis also share odontodes at tip of snout almost as long as wide, spatulate and with tip rounded or heart-shaped, similar to those described for P. jumbo by Britski \& Garavello (2002). These authors state that the same kind of odontodes was found in Hypostomus pusarum, but is also present in at least two other Hypoptopomatinae species, Microlepidogaster dimorpha Martins \& Langeani and M. perforatus Eigenmann \& Eigenmann (Martins \& Langeani, 2011). Parotocinclus seridoensis also shares with $P$. spilurus the presence of laterally exposed pectoral girdle not found in P. bidentatus and P. muriaensis. According to the results of a phylogenetic parsimony analysis including the Hypoptopomatinae members, P. bidentatus and P. muriaensis are considered sister-taxa (Gauber \& Buckup, 2005). However, in this analysis $P$. spilurus, the single species described at the time with rudimentary adipose fin, was not included. Parotocinclus seridoensis differs from $P$. bidentatus, $P$. muriaensis and $P$. spilurus by presenting the abdomen almost entirely naked (Fig. 3), having only a single row of reduced elongate plates on each side and a few rounded platelets irregularly distributed on the preanal region, while $P$. bidentatus, $P$. muriaensis and $P$. spilurus have conspicuous lateral plates and abdomen mostly covered by plates.

Extensively naked abdomen with a mosaic of few rounded platelets is also present in some Parotocinclus species from northeastern Brazil: P. arandai, P. bahiensis, P. minutus Garavello, P. spilosoma (Fowler), P. cearensis, and $P$. cesarpintoi (Sarmento-Soares et al., 2009), while P. robustus Lehmann \& Reis and P. prata Ribeiro, Melo \& Pereira, both from the rio São Francisco basin, have the abdomen completely devoid of dermal plates (Lehmann \& Reis, 2012).

Most individuals of $P$. seridoensis also present an area deprived of odontodes at the anterior border of the snout shaped as an inverted $\mathrm{V}$ or $\mathrm{U}$, a feature discriminating individuals of the new species from P. spilurus whose anterior border of the snout is covered by regular rows of odontodes (Fig. 7).

Parotocinclus spilurus and $P$. seridoensis occur in adjacent river basins of the Mid-Northeastern Caatinga region, the former from the rio Jaguaribe basin and the latter from the rio Piranhas-Açu basin. Although these are the largest and main hydrographic basins of this region, both species are apparently restricted to the upper portions of the rio Jaguaribe and Piranhas-Açu basins, respectively. If the above mentioned characters represent synapomorphies between $P$. spilurus and $P$. seridoensis, indicating a sister-species relationship, it is possible that a vicariant process, due to common tectonic activation in northeastern Brazil (Lima, 2000; Bezerra et al., 2006), around the Chapada de Apodi region, the watershed divide between rio Jaguaribe and Piranhas-Açu basins, could be involved in the origin of these species. A similar pattern of closely related species found in the same area is the occurrence of Pseudoancistrus genisetiger Fowler in rio Jaguaribe basin and $P$. papariae in rio Piranhas-Açu basin.

Of the 27 Parotocinclus valid species so far described, twelve occur in northeastern Brazil, representing approximately $44.4 \%$ of the known species (Sarmento-Soares et al., 2009; Lehmann \& Reis, 2012). Among these species, five occur in eastern Atlantic coastal basins (P. arandai, P. bahiensis, P. cristatus Garavello, P. jimi Garavello, and P. minutus), six in Mid-Northeastern Caatinga region ( $P$. cearensis, $P$. cesarpintoi, $P$. jumbo, $P$. seridoensis, $P$. spilosoma, and $P$. spilurus), and one in the rio Parnaíba basin ( $P$. haroldoi). The two species known from rio São Francisco basin ( $P$. prata and $P$. robustus) were only recorded from tributaries of the upper and middle portions of the basin, in Minas Gerais State, southeastern Brazil (Lehmann \& Reis, 2012). 
With the exception of $P$. jumbo, the Parotocinclus species from Mid-Northeastern Caatinga region have restricted geographic distribution, usually found in a single basin (Rosa et al., 2003; Sarmento-Soares et al., 2009). Parotocinclus jumbo occurs in many basins of the Mid-Northeastern Caatinga region (Jaguaribe, Piranhas-Açu, Paraíba do Norte, and Mundaú river basins; Britski \& Garavello, 2002), and in the rio São Francisco basin (Lehmann \& Reis, 2012), usually in sympatry with other congeners, possibly representing a species complex, that when studied in detail, based on morphological and molecular data, can shed light on past connections and posterior fragmentation of the northeastern Brazilian basins.

Material examined. Parotocinclus cearensis: MNRJ 8689, 10, paratypes, 20.6-24.2 mm SL, Brazil, Ceará State, Ipu, Cachoeira do Gusmão; MNRJ 10155, 1, paratype, $21.3 \mathrm{~mm}$ SL, Ipu, Cachoeira do Gusmão; UFRN 388, 4, 19.5-32.5 mm SL, Ceará State, Lima Campos, rio Lima Campos, 6²4'13.7”S 3857'19.4”W; UFRN 404, 2, 24.3-25.4 mm SL, from same locality; UFPB 7643, 2, Itatira, leaking of the barrage Oiticica, rio Jaguaribe basin, $4^{\circ} 40^{\prime} 36.5^{\prime \prime} \mathrm{S}$ $39^{\circ} 41^{\prime} 6.5^{\prime}$ W. P. cesarpintoi: MNRJ 1022, 10, syntypes, 34.6-41.6 mm SL, Brazil, Alagoas State, Quebrângulo, Riacho Quebrângulo; MNRJ 1154, 10, syntypes, 25.8-29.4 mm SL, Rio Paraíba do Meio; UFRN 1132, 28 (2 c\&s), 28.3-39.6 mm SL, rio Paraíba do Meio, 9²1'55.8”S 36²5'10.6”'W; UFPB 9015, 4, 19.1-29.4 mm SL, Canapi, rio Canapi, 96'57.4"S 37³6'31.4”W. UFPB 9016, 3, 29.2-32.4 mm SL, Mata Grande, rio Verde, 900'3.0”S 37³9'39.6”W. P. haroldoi: UFPB 7033, 1, 19.4 mm SL, Brazil, Ceará State, Ibiapaba, rio Poti, rio Parnaíba basin, 5²'43.9”S 4055'19.8”'W; UFPB 7340, 84, 15,79 -24.6 mm SL, Piauí State, Piracuruca, rio Parnaíba basin, $3^{\circ} 44^{\prime} 0.01^{\prime \prime S}$ 41 ${ }^{\circ} 40^{\prime} 56.4^{\prime \prime}$ W. P. jumbo: UFPB 4118, 6, paratypes, 23.0-27.4 mm SL, Brazil, Paraíba State, Sapé, rio Gurinhem at bridge on road PB 055, 708'54"S 35¹4'03"W; UFPB 4024, 9, 25.2-28.5 mm SL, Salgado do São Felix, rio Paraíba do Norte, $7^{\circ} 21^{\prime} 31.2^{\prime \prime}$ S $35^{\circ} 27^{\prime} 31.0^{\prime \prime W}$; UFRN 309, 22, 10.9-31.5 mm SL, Rio Grande do Norte State, Jardim de Piranhas, Rio Piranhas, 6²2'40.3”S 37²1'19.3”W; UFPB 9010, 80, 21.9-36.4 mm SL, Alagoas State, Canapi, rio Canapi, 96'57.4”S 37³6’31.4”W; UFPB 9011, 60, 19.8-31.6 mm SL, Mata Grande, riacho Verde, 96'3.0"S 37³9'39.6”W; UFPB 7419, 37, 27.7-30.2 mm SL, Sergipe State, Porto da Folha, rio Campos Novos, rio São Francisco basin, 954'20.1”S 37²3'17.5”W; UFPB 7177, 2, 21.8$25.7 \mathrm{~mm}$ SL, Pernambuco State, Serra Talhada, rio Açude José Alves, 759'8.8'S 38 16'24.7'W. P. maculicauda: UFRN 1010, 10, 23.0-33.7 mm SL, Brazil, Rio de Janeiro State, Silva Jardim, rio São João, 22³4'58.53”S 42³4'30.73”W. P. spilosoma: UFRN 0462, 21, 17.83-41.40 mm SL, Brazil, Paraíba State, tributary to rio Paraíba do Norte between Boqueirão e Queimadas in road PB-148, 7²4'26"S 360'34.6”W. UFRN 698, 19 (1 c\&s), 19.6-40.4 mm SL, Cruz do Espírito Santo, rio Paraíba do Norte, $7^{\circ} 8^{\prime} 57.6^{\prime \prime}$ 'S 357'17.8”W; UFRN 1584, 5, 25.5-29.2 mm SL, in road PB-104, Barra de Santana, rio Paraíba do Norte, $7^{\circ} 31^{\prime} 45^{\prime}$ 'S 3559'55.3”W. P. spilurus: UFRN 321, 14 (1 c\&s), 12.2-41.9 mm SL, Brazil, Ceará State, Lima Campos, rio Lima Campos, 6²4'13.7”S 3857'19.4”W; UFRN 345, 1, 33.8 $\mathrm{mm}$ SL, Sabueiro, rio Jaguaribe, 6³2'31.1”S 3954'32.5”W; UFPB 336, 7, 21.7-31.0 mm SL, Barbalha, Rio Salamanca; UFPB 9012, 9, topotypes, 17.7-31.3 mm SL, Icó, rio Salgado, rio Jaguaribe basin, 624'28.9"S 3852'6.6”W; UFPB 9013, 3, 28.5-39.4 mm SL, Lavras da Mangabeira, Machado, small stream tributary to Rio Salgado, rio Jaguaribe basin, $6^{\circ} 42^{\prime} 25.7^{\prime \prime S} 39^{\circ} 1^{\prime} 40.4^{\prime \prime} \mathrm{W}$.

\section{Acknowledgments}

We are most thankful to Pablo Lehmann (UNISINOS) for helpful comments on hypoptopomatine catfish descriptions and to Pedro H. S. Medeiros, João P. S. Medeiros and Judas T. de Medeiros for logistic support in Caicó. To Cinara P. Neves, Carlos E. R. D. Alencar, Dauiane Ferreira, Francisca G. S. O. Landim, Mateus Germano, Márcio J. da Silva, Roney E. C. de Paiva, and Waldir M. Berbel-Filho for helping during fieldwork. We also thank to Naércio A. Menezes for their critical reviews that improved the quality of this manuscript. Collections were made under permit 326561/2012 MMA/ICMBio/SISBIO from Ministério Brasileiro do Meio Ambiente/Instituto Chico Mendes de Conservação da Biodiversidade/Sistema de Autorização e Informação em Biodiversidade. This study was supported by $\mathrm{CNPq} /$ ICMBio (Conselho Nacional de Desenvolvimento Científico e Tecnológico/ Ministério de Ciências e Tecnologia; proc. 552086/2011-8). TPAR receives DCR (Desenvolvimento Científico Regional) post-doctoral fellowship by CNPq/ FAPERN (Fundação de Apoio à Pesquisa do Estado do Rio Grande do Norte, proc. 350674/2012-4).

\section{Literature Cited}

Abell, R., M. L. Thieme, C. Revenga, M. Bryer, M. Kottelat, N. Bogutskaya, B. Coad, N. Mandrak, S. L. Balderas, W. Bussing, M. L. J. Stiassny, P. Skelton, G. R. Allen, P. Unmack, A.

Naseka, R. Ng, N. Sindorf, J. Robertson, E. Armijo, J. Y. Higgins, T. J. Heibel, E. Wikramanayake, D. Olson, H. L. López, R. E. Reis, J. G. Lundberg, M. H. S. Pérez \& P. Petry. 2008. Freshwater ecoregions of the world: a new map of biogeographic units for freshwater biodiversity conservation. Bioscience, 58: 403-414.

Bezerra, F. H. R., J. M. Ferreira \& M. O. M. Souza. 2006. Review of seismicity and Neogene tectonics in the northeastern Brazil. Revista de la Asociación Geológica Argentina, 61: 525-535.

Britski, H. A. \& J. C. Garavello. 2002. Parotocinclus jumbo, a new species of the subfamily Hypoptopomatinae from northeastern Brazil (Ostariophysi: Loricariidae). Ichthyological Exploration of Freshwaters, 13: 279-288.

Britski, H. A. \& J. C. Garavello. 2009. Redescription of Parotocinclus bahiensis (Miranda-Ribeiro, 1918) (Pisces, Ostariophysi, Loricariidae). Zootaxa, 2143: 59-67.

Carvalho, T. P., P. A. Lehmann \& R. E. Reis. 2008. Gymnotocinclus anosteos, a new uniquely-plated genus and species of loricariid catfish (Teleostei: Siluriformes) from the upper rio Tocantins basin, central Brazil. Neotropical Ichthyology, 6: 329-338.

Carvalho, T. P. \& R. E. Reis. 2009. Four new species of Hisonotus (Siluriformes: Loricaridae) from the upper rio Uruguay, southeastern South America, with a review of the genus in the rio Uruguay basin. Zootaxa, 2113: 1-40.

Eigenmann, C. H. \& R. S. Eigenmann. 1889. Preliminary notes on South American Nematognathi II. Proceedings of the California Academy of Sciences, 2: 28-56. 
Eigenmann, C. H. \& R. S. Eigenmann. 1890. A revision of the south America Nematognathi or cat-fishes. Occasional Papers of the California Academy Sciences, 1: 1-508.

Fowler, H. W. 1941. A collection of fresh-water fishes obtained in eastern Brazil by Dr. Rodolpho von Ihering. Academy of Natural Sciences Philadelphia, 93: 123-199.

Garavello, J. C. 1977. Systematics and geographical distribution of the genus Parotocinclus Eigenmann \& Eigenmann, 1889 (Ostariophysi, Loricariidae). Arquivos de Zoologia, 28: 1-37.

Gauger, M. F. W. \& P. A. Buckup. 2005. Two new species of Hypoptopomatinae from the rio Paraíba do Sul basin, with comments on the monophyly of Parotocinclus and the Otothyrini (Siluriformes: Loricariidae). Neotropical Ichthyology, 3: 509-518.

Langeani, F., P. A. Buckup, L. R. Malabarba, L. H. R. Py-Daniel, C. A. Lucena, R. S. Rosa, J. A. S. Zuanon, Z. M. S. Lucena, M. R. Britto, O. T. Oyakawa \& G. Gomes-Filho. 2009. Peixes de água Doce. Pp. 211-230. In: Rocha R. M. \& W. A. P. Boeger (Orgs.). Estado da arte e perspectivas para a Zoologia no Brasil. Curitiba, Brasil.

Lehmann, P. A. \& R. E. Reis. 2012. A new species of Parotocinclus (Siluriformes: Loricariidae) from the upper Rio São Francisco, Brazil. Zootaxa, 3390: 56-64.

Lehmann, P. A. 2006. Anatomia e relações filogenéticas da família Loricariidae (Ostariophysi: Siluriformes) com ênfase na subfamília Hypoptopomatinae. Unpublished Ph.D. Dissertation, Pontifícia Universidade Católica do Rio Grande do Sul, Porto Alegre, 420p.

Lima, C. C. U. 2000. O Neotectonismo na costa do Sudeste e Nordeste Brasileiro. Revista de Ciência e Tecnologia, Universidade de Guarulhos, 15: 91-102.

Lima, L. C. 2005. Além das águas, a discussão no Nordeste do rio São Francisco. Revista do Departamento de Geografia, 17: 94-100.

Martins, F. O. \& F. Langeani. 2011. Microlepidogaster dimorpha, a new species of Hypoptopomatinae (Siluriformes: Loricariidae) from the upper rio Paraná system. Neotropical Ichthyology, 9: 79-86.

Medeiros, E. S. F., M. J. Silva, B. R. S. Figueiredo, T. P. A. Ramos \& R. T. C. Ramos. 2010. Effects of fishing technique on assessing species composition in aquatic systems in semi-arid Brazil. Brazilian Journal of Biology, 70: 255-262.

Reis, R. E., E. H. L. Pereira \& P. A. Lehmann. 2012. A new genus and species of Hypoptopomatine catfish from the upper rio São Francisco basin, Brazil. Copeia, 2012: 6-11.

Ribeiro, A. C., A. L. A. Melo \& E. H. L. Pereira. 2002. A new species of Parotocinclus (Siluriformes: Loricariidae) from the rio São Francisco basin, southeastern Brazil. Ichthyological Exploration of Freshwaters, 13: 217-224.
Rosa, R. S., N. A. Menezes, H. A. Britski, W. J. E. M. Costa \& F. Groth. 2003. Diversidade, padrões de distribuição e conservação dos peixes da Caatinga. Pp. 135-180. In: Leal, I. L., M. Tabareli \& J. M. C. da Silva (Eds.). Ecologia e conservação da Caatinga. EDUFPE, Recife, Brasil.

Rosa, R. S. 2004. Diversidade e conservação dos peixes da caatinga. Pp. 149-161. In: Silva, J. M. C., M. Tabarelli, M. T. Fonseca \& L. V. Lins (Eds.). Biodiversidade da Caatinga: Áreas e Ações

Prioritárias para a Conservação. Brasília, Ministério do Meio Ambiente.

Sarmento-Soares, L. M., Lehmann, P. \& R. F. Martins-Pinheiro. 2009. Parotocinclus arandai, a new species of hypoptopomatine catfish (Siluriformes: Loricariidae) from the upper rio Jucuruçu and Buranhém, states of Bahia and Minas Gerais, Brazil. Neotropical Ichthyology, 7: 191-198.

Schaefer, S. A. 1991. Phylogenetic analysis of the loricariid subfamily Hypoptopomatinae (Pisces: Siluriformes: Loricariidae), with comments on generic diagnosis and geographic distribution. Zoological Journal of the Linnean Society, 102: 1-41.

Schaefer, S. A. 1997. The Neotropical cascudinhos: Systematics and biogeography of the Otocinclus catfishes (Siluriformes: Loricariidae). Proceedings of the Academy of Natural Sciences of Philadelphia, 148: 1-120.

Schaefer, S. A. 1998. Conflict and resolution: impact of new taxa on phylogenetic studies of the neotropical cascudinhos (Siluroidei: Loricariidae). Pp. 375-400. In: Malabarba, L. R., R. E. Reis, R. P. Vari, Z. M. Lucena \& C. A. Lucena (Eds.). Phylogeny and classification of neotropical fishes. Edipucrs, Porto Alegre.

Silva, D. M., F. Riet-Correa, R. M. T. Medeiros \& O. F. Oliveira. 2006. Plantas tóxicas para ruminantes e eqüídeos no Seridó Ocidental e Oriental do Rio Grande do Norte. Pesquisa Veterinária Brasileira, 26: 223-236.

Taylor, W. R. \& G. C. Van Dyke. 1985. Revised procedures for staining and clearing small fishes and other vertebrates for bone and cartilage study. Cybium, 9: 107-109.

Submitted April 22, 2013 Accepted September 4, 2013 by Marcelo Britto Published December 27, 2013 